Makwembere, S. et al. Lecturer Autoethnographies of Adjusting to Online Student Interactions during COVID-19

\title{
Lecturer Autoethnographies of Adjusting to Online Student Interactions during COVID-19
}

\author{
Sandra Makwembere*1 ${ }^{*}$ Obert Matarirano ${ }^{1} \&$ Nobert R. Jere $^{1}$ \\ *Corresponding Author: smakwembere@wsu.ac.za \\ 1. Walter Sisulu University, Buffalo City Campus, South Africa \\ Received : 2021-06-15 \\ Revised : 2021-08-01 \\ Accepted : 2021-08-24 \\ d. \\ $10.46303 /$ ressat.2021.16
}

\begin{abstract}
How to cite this paper: Makwembere, S., Matarirano, O. \& Jere, N.R. (2021). Lecturer Autoethnographies of Adjusting to Online Student Interactions during COVID-19. Research in Social Sciences and Technology, 6(2), 148-168. https://doi.org/10.46303/ressat.2021.16

This is an Open Access article distributed under the terms of the Creative Commons Attribution 4.0 International license (https://creativecommons.org/licenses/by/4.0/).
\end{abstract}

\begin{abstract}
In 2020, the COVID-19 pandemic pushed South African historically disadvantaged institutions, that had not yet reached advanced levels of technology use in teaching and learning, to find immediate solutions to salvage the disrupted academic year. Interactions with students, which had predominantly been face-to-face, shifted to various online platforms for lecturers to adopt emergency remote teaching approaches. Most of the lecturers were unprepared or incapacitated to make the shift to online environment. Studies have looked at the online teaching and learning experiences of students and lecturers during the COVID-19 pandemic but very few have taken an autoethographic approach to their inquiry and situated experiences in historically disadvantaged institutions. In this article, as lecturers, we use autoethnographies to provide an account of adjusting to interacting with students online during national lockdowns at a historically disadvantaged institution. The Social Cognitive Theory (SCT) was applied to guide the study. This reflexive approach is valuable, as it captures professional encounters and reflections needed to understand the effects of rapid changes to teaching and learning in response to the pandemic. Given the education disparities that already existed between South African higher education institutions before COVID-19, the article contributes to the discourse on how historically disadvantaged institutions can advance higher standards of teaching and learning to serve students better. Our reflections point to the personal, technical and structural challenges of maintaining regular online interaction. Our findings show that different approaches and techniques were applied to adjust to virtual teaching and learning. As teaching and learning methodologies have the potential to ingrain social inequalities, we made recommendations on how to improve online interactions with students from historically disadvantaged contexts.
\end{abstract}

Keywords: Autoethnography; COVID-19; emergency remote teaching; higher education; historically disadvantaged institutions; lecturers 
Makwembere, S. et al. Lecturer Autoethnographies of Adjusting to Online Student Interactions during COVID-19

\section{Introduction}

The global outbreak of the coronavirus (COVID-19) has undoubtedly placed significant pressure on higher education institutional capacities across the world to adapt. The contagious nature of the virus resulted in the World Health Organisation declaring it a pandemic on 11 March 2020. Education institutions in different countries had to adjust to the situation by introducing measures such as mandatory social distancing and confinement. According to the United Nations Educational, Scientific and Cultural Organisation (UNESCO), by 1 April 2020, schools and universities in 185 countries had closed, which significantly affected academic calendars and continuity of teaching and learning (UNESCO, 2021).

In South Africa, online learning and emergency remote teaching were immediately prioritised when the pandemic was declared. At universities, in particular, students and academics were expected to engage fully online from the end of April into early May 2020. Resources were redirected to secure laptops and internet data and trainings were conducted to orient academics and students for what would be expected. Whether or not academics and students felt sufficiently prepared for what lay ahead, no accurate prediction could have been made on how universities would fare during the global crisis. Lessons learnt are still being captured. When they reopened, many nations turned to information and communication technologies to facilitate learning processes at all education levels and some even made online learning compulsory. This COVID-19 facilitated a shift in education instruction and has created a range of challenges and opportunities still being uncovered by researchers, institutions and policymakers.

For historically disadvantaged institutions (HDIs), largely characterised by a series of challenges such as a lack of financial and human resources and infrastructure, emergency remote teaching (ERT) exposed many gaps and capacity limits, which brings to light the need to reflect on the adjusted academic year 2020 (Andreu \& Nussbaum, 2009; Matarirano et al., 2021a). The label, HDIs, refers to a group of universities that catered for the Black population under the former apartheid regime (Nyoni, 2020). Higher education systems were divided along racial lines (Deparment of Higher Education and Training, 2014). There were 'Black' universities for the Black majority (racially classified as African, Coloured and Indian) and 'White' universities for the White minority (Deparment of Higher Education and Training, 2014). Resources for Black universities were not prioritised, thus, this band of universities suffered several constraints (Chetty \& Pather, 2015; Mekoa, 2018). Post-apartheid, the designation 'historically disadvantaged institution' was adopted by the government to recognise past higher education injustices and direct redress of the severe disparities between these universities and former 'white' universities. The label provides a kind of support such as funding opportunities. For example, the Historically Disadvantaged Institutions Development Grant is meant to develop public universities classified as historically disadvantaged (Matarirano et al., 2021b).

Six universities have been identified and classified: the University of Fort Hare, University of Limpopo, University of Venda, University of Zululand, University of Western Cape and Walter Sisulu University (Deparment of Higher Education and Training, 2014). Currently, these universities cater to rural students in particular, who mostly have disadvantaged backgrounds, braced with inequalities even in basic education (Matarirano et al., 2021a). Because of their results and financial incapacitation, these students face many barriers to entering affluent 
Makwembere, S. et al. Lecturer Autoethnographies of Adjusting to Online Student Interactions during COVID-19

universities such as the University of Stellenbosch and the University of Pretoria, which are both expensive and have high entry requirements (Chetty \& Pather, 2015).

Some universities began online teaching as late as July because of these challenges while other affluent universities had already completed their first semester by then. Many students from disadvantaged backgrounds were left confused, anxious, frustrated and unsure about the future (Aristovnik et al., 2020). Transitioning to online learning was abrupt and unplanned, hence caught many institutions off guard. Both students and lecturers were unprepared. Lecturers had to rethink their teaching methods so that they could quickly respond to matters such as students struggling with online learning. As lecturers at a HDI during the period, we experienced these challenges first hand.

This paper summarises our autoethnographies as three lecturers at a HDI where we had to adjust to interacting with students online in our roles. Research into the effects of COVID-19 on HDIs is still growing. To date, research particularly centred on providing lecturers' views on how they have responded to changing teaching and learning situations due to the shift to online interactions, is arguably limited. These lecturer perspectives are vital when considering the silences that have historically existed in these institutions. Research that gives a voice to the insights and realities of lecturer professional encounters can translate into discoveries of hidden thoughts and feelings knitted into the stories of academic survival. Autoethnography brings to the fore opportunities to express unheard or silenced stories, thus fostering inclusion by allowing many voices on the experiences of the effects of COVID-19 on teaching and learning.

What follows summarises the impact of COVID-19 on higher education teaching and learning, then, a description of some challenges faced by South African HDIs as a backdrop to the relevance of the study about existing research on the effects of COVID-19 on Higher Education Institutions (HEIs). Next, the theoretical framework used is then summarised and this is followed by a summary of the autoethnographic approach. A presentation and analysis of autoethnographic accounts subsequently follow this section. The accounts highlight the ways lecturers experienced adjusting to online student interaction. The paper ends with an appraisal of the autoethnographic experience and recommendations for future inquiries into the effects of COVID-19 at HDIs considering the accounts.

\section{Research Question and Objective}

The primary objective of the paper was to present the reflections on the activities, actions and adjustments that were taken by the selected lecturers. The study was guided by the Social Cognitive Theory. The following research question was addressed:

How did lecturers experience and adjust to online interactions with students from a HDI during lockdown in the 2020 academic year?

\section{Literature Review}

\section{Impact of COVID-19 on higher education teaching and learning}

COVID-19 being a highly contagious disease, resulted in high mortalities leading to a series of lockdowns globally. The disease was identified in China at the close of 2019 and by March 2020, the infection had spread to many countries, compelling the World Health Organisation to declare it a global pandemic on the $11^{\text {th }}$ of March 2020 (Rashid \& Yadav, 2020). Due to the 
Makwembere, S. et al. Lecturer Autoethnographies of Adjusting to Online Student Interactions during COVID-19

serious nature of the infections and the lack of solid aetiology and pathogenesis regarding COVID-19, governments responded by adopting 'social distancing' as a way of reducing physical contact, which facilitates its spread. HEls, as spaces where large proportions of people congregate, became potential hotspots for COVID-19. The immediate impact of COVID-19 on HEls was the disruption of academic programmes. Face-to-face learning was halted and examinations were postponed. What followed were swift shifts to digital learning as a mandatory mode of learning, sometimes without proper planning and capacitation (Sahu, 2020; ). Though there have been discussions on how best to adopt technologies, at the moment with the continuous rise in COVID-19 cases, online teaching and learning remain a priority.

The use of online media has been embraced by close to $90 \%$ of HEls globally, as the new normal, to date (Aristovnik et al., 2020). While the sudden introduction of e-learning into HEls came as a contingency, it has created opportunities for advancements in teaching and learning as well as exposed the weaknesses of traditional methods, particularly face-to-face learning. Onlinebased learning amplifies certain roles expected of lecturers, particularly mentorship and encouragement. Because of the uncertainties and anxieties, lecturers attempted to encourage their students to embrace online learning so that they were not left out, regardless of limitations (Rashid \& Yadav, 2020). In a global survey on the impact of COVID-19 on HEls, Aristovnik et al. (2020) reported that most lecturers felt an increase in workload with digital learning that required them to use skills which they were not trained for.

Digital learning has bridged the effect of geography on the dissemination of knowledge. It is now more apparent for HEls that used traditional methods before COVID-19 induced changes that the learning process is not solely bound by physical space or time. Concerning the social well-being of both students and lecturers at HEls though, the detachments from campus have negatively affected both, especially regarding mental health (Yorguner, Bulut \& Akvardar, 2021; Meishar-Tal \& Levenberg, 2021). This has led to HEls questioning the psychosocial effects of COVID-19 and whether the move from face-to-face learning has been worth it.

Face-to-face learning has traditionally been the primary mode of learning in HEls (Gherheș et al., 2021). It involves the use of an enclosed physical environment where the student and instructor can use their five senses in transferring knowledge (Bandara \& Wijekularathna, 2017). The method has been favoured for the ability to allow close interaction between the student and lecturer. The interpersonal student-lecturer relationship allows the students to be more at ease to ask questions and receive clarifications, thereby getting a better understanding of the content as opposed to online means (Julien \& Dookwah, 2020). Face-to-face learning promotes social interaction and networking among students, which enlarges learning besides the course content. Thus, COVID-19 has necessitated a change in the skills development trajectory of students and the need to equip lecturers to appropriately guide students (Khogali, 2020; Radha et al., 2020; Joia \& Lorenzo, 2021).

Online learning transfers knowledge through digital means such as a digital learning management system and students are physically isolated from their lecturers or institutions (Pozzi et al., 2019; Kalimullina et al., 2021). Under COVID-19, it has emerged as emergency remote teaching and learning (ERTL), which is an interim mode until the pandemic has normalised (Gherheș et al., 2021). Some scholars predicted that online learning as a system might replace traditional face-to-face learning and argued that the growing costs of education 
Makwembere, S. et al. Lecturer Autoethnographies of Adjusting to Online Student Interactions during COVID-19

and the convenience of working while pursuing education may increase the need for online learning (Arias et al., 2018). Also, online learning benefits such as flexibility and reduction in the cost of acquiring education by reducing transport and accommodation costs (Naveed et al., 2017) would become attractive. It helps address challenges of accessing curricula where there are physical infrastructure limits.

In resource-limited institutions, the lack of buildings and physical infrastructure are not the only issues that impede teaching and learning, therefore, online learning is not necessarily an immediate remedy. Typically, such institutions also lack skills, software and digital infrastructure necessary to implement online learning. For the students from poor backgrounds, they characteristically lack electricity, computers and have poor internet connectivity, which are necessary for the success of the roll-out of online-based learning (Sahu, 2020; Baldwin \& Bekithemba, 2021). These situations cause great anxiety and uncertainty among students trying to learn using this mode and this affects their performance (Aristovnik et al., 2020). Lecturers must play an important role in mentoring and guiding the students constructively. Students from disadvantaged communities require motivation and encouragement to avoid fears and anxiety. For lecturers, anxieties and uncertainties have been cited in studies, however, there are opportunities for further interrogations of online learning as COVID-19 persists.

Many HEls have diversified the technologies they use to facilitate the dissemination of knowledge. The technologies vary from digital libraries to online media for lectures (Andreu \& Nussbaum, 2009). Open Educational Resources (OERs) have been useful resources as they are available in the public domain with no restrictions (Andreu \& Nussbaum, 2009). Examples of OERs include open access journals, open textbooks, streaming videos and online tutorials among others. The use of OERs by HEls has enabled students from all backgrounds and geographic regions to access cost-free information, thereby improving their access to quality education (Li et al., 2015).

Flipped classrooms are another type of technology increasingly used. With flipped classrooms, students access their lectures, course material and assessments online (Li et al., 2015). The concept reverses the traditional roles of instructors, allowing students to research a certain topic before coming to class (Fulton, 2012). The students have the liberty of accessing the material at their time, hence promoting independence. Visio-audio technology including video conferencing platforms such as Moodle, Zoom, MS Teams and BigBlueButton, have also become popular across HEIs (Aristovnik et al., 2020). Aristovnik et al. (2020) reported that $60 \%$ of students globally were familiar with these platforms. These systems have many benefits such as facilitating real-time meetings to occur. Even the use of messaging platforms such as WhatsApp, which were mostly used for social reasons, is now encouraged by HEls to convey information to students (Aristovnik et al., 2020). All these different technologies require many adjustments for students and lecturers. It can be expected that these adjustments will differ depending on the HEl context.

\section{Challenges of South African Historically Disadvantaged Institutions}

Poor academic performance characterises historically disadvantaged universities, with dropout rates being high and throughput rates being low (Badat, 2010). This poor academic performance has been linked to a lack of financial resources to improve the quality of education 
Makwembere, S. et al. Lecturer Autoethnographies of Adjusting to Online Student Interactions during COVID-19

and enrolment (Badat, 2010), a lack of infrastructure such as buildings and computers (Sonn, 2016) as well as low staff capacities and capabilities. The resource and capacity constraints, thus create a cycle of events where poorly performing students are enrolled in an institution lacking resources and the output continues to be poor as compared to advantaged universities (Sonn, 2016). Student protests at these HEls expose the challenges students still face such as lack of accommodation and funding due to developmental backlogs and delays (Matarirano et al., 2021b).

Online learning is taking place at HDIs with limited resources. COVID-19 and the subsequent lockdowns have meant that these institutions have been forced to scale up their plans for technology use to enable digital learning (Sahu, 2020). With online learning as a priority for HDIs, several questions have been raised around how to achieve inclusive learning in the face of the realities of poor resources to optimally achieve online learning objectives. According to Matarirano et al. (2021a), various changes such as in attitudes, behaviours and decisions are needed at different levels (institutional, collective and individual). While COVID-19 persists, much can be discovered about how HDIs are learning to adjust. This is vital for recognising the agencies operating at different levels that need to be activated to support inclusive higher education transformation under the pandemic and beyond it.

\section{Social cognitive theory}

Social cognitive theory (SCT) can help ground an understanding of how individuals adapt to change, in this case, how lecturers adapt to the demands of online learning under COVID-19. This article uses some aspects of Bandura's social cognitive theory to understand our adjustment experiences as lecturers from a historically disadvantaged institution. The basic principles of the theory point to human behaviour being learnt by observing others and modelling their behaviour. Cognitive, social and behavioural influences all play a role in learning (Bandura, 1971, 1977, 1986, 1999, 2001, 2005). During the period under study, our thoughts, behaviours and actions were influenced by our abilities, observations and direct experiences of the events that took place in our learning environment. Issues such as limited resources, unstable internet connections and the flexibility of remote teaching affected on how we approached our roles as teachers. The SCT provided explanatory lenses to how we adjusted to the changes that were happening.

Learning, according to SCT, occurs in social situations where people interact with one another. Human functioning is construed to be a product of the dynamic interplay between personal (experiences, skills, cognitions, beliefs, affect), behavioural (responses to stimuli) and environmental (external social context) influences (Bandura, 2005; Schunk \& Usher, 2012). This interplay between these variables is graphically illustrated in Figure 1 . The environment can impact behaviour but people may also affect the environment by their ideas and actions. Individuals learn skills, techniques, beliefs, rules, attitudes and the appropriateness, usefulness and repercussions of behaviours through encounters. Individuals act under their perceptions of their skills and the predicted consequences of their actions (Schunk \& Usher, 2012). 
Makwembere, S. et al. Lecturer Autoethnographies of Adjusting to Online Student Interactions during COVID-19

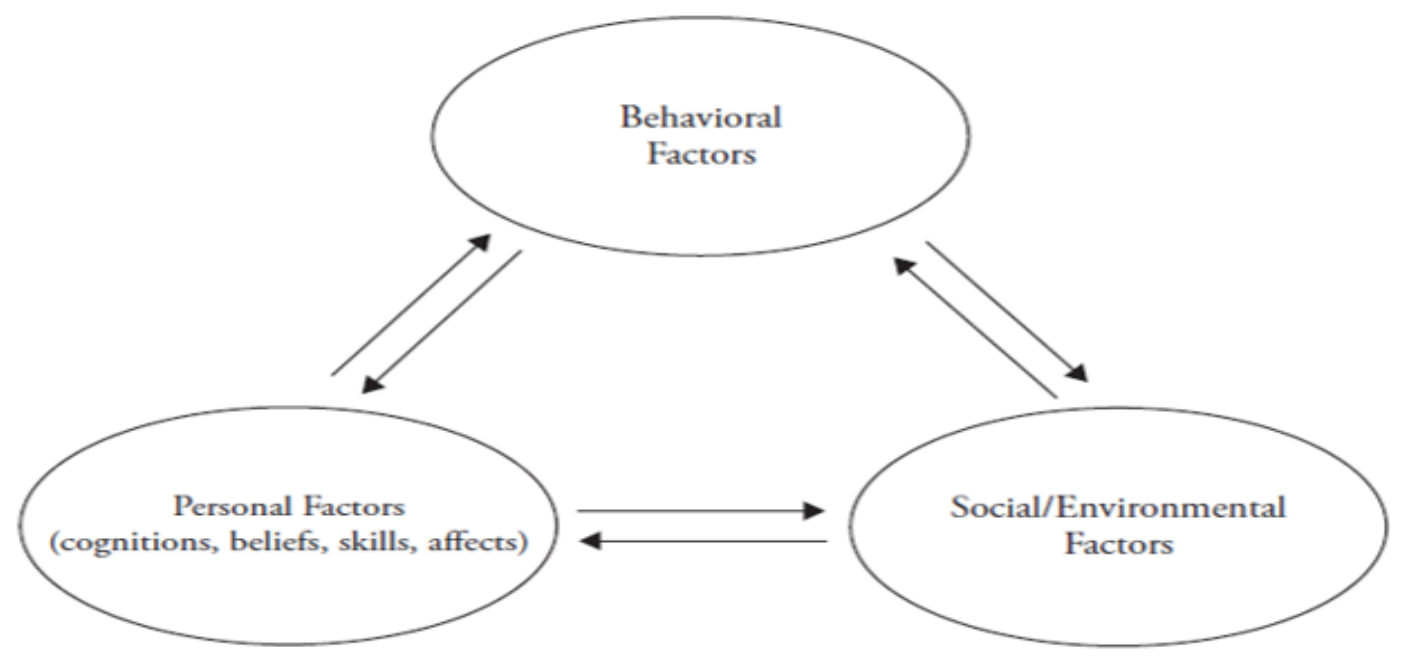

Figure 1. Reciprocal interactions. Adapted from Social cognitive theory and motivation by D.H. Schunk and E.L. Usher, 2012. Copyright 2012 by American Psychological Association.

The concept of agency, where people intentionally influence the functioning and life circumstances of others in development, adaptation and change, underpins SCT. Intentionality and forethought are key features of human agency. Intentionality relates to the action plans and strategies that people use to achieve their goals. As Bandura (2005) pointed out, goals and standards guide and motivate people, the expectations to effectively facilitate student learning, complete syllabuses and create lifelong learners guided us in our quest to find ways to achieve these expectations. It was our agentic powers, through our experiences and abilities that enabled us to attain the goals despite the difficult and minimally supportive environment we found ourselves in. Self-efficacy, described as a belief in one's ability to perform a particular task (Bandura, 1986), was critical in exercising our agency (Bandura, 1999). As Fertman \& Primack (2009) argued, self-efficacy determines how people behave. The beliefs we had as lecturers were key in pursuing and attaining the teaching goals.

In exercising our agency, the environment we operated in influenced us but we also influenced it on our own or in our departments and faculties as groups. The platforms we used and the approaches to instruct, assess and interact with students were a product of our individual and group agency. These changes were largely influenced by our high efficacy levels. As Bandura (2005) argued, the efficacy of people plays a crucial role in how they organise, create and manage life circumstances that affect what they become in life.

Contrary to the behaviourist theory which explained learning as occurring with changes of behaviour, Bandura (1977) argued that learning is acquired from the social environment and may occur with or without change of behaviour. With this, Bandura accounted for the type of learning that direct reinforcement failed to account. In effect, SCT helps us to understand how individual lecturers, adapting to interacting with students online, are influenced by and influence their environments as there is constant interaction between themselves and their teaching environments (in this case, HDI environments). 
Makwembere, S. et al. Lecturer Autoethnographies of Adjusting to Online Student Interactions during COVID-19

\section{Methodology}

\section{Research design}

A qualitative approach was chosen and an autoethnographic research design was used. Autoethnography was selected because HDIs have a past of exclusion and marginalisation and it was deemed an approach appropriate to capture experiences in this context. Retrospective autoethnography, in particular, was chosen because the participants had to recall past events of the 2020 academic year. As Schmid (2019, p. 265) argues, autoethnography "facilitates inclusion and allows for multiple voice(s) and knowledge(s) and thus adds to our collective, multifaceted understanding of South Africa". As a "deeply personal research approach... [it links] identity and culture as well as the individual and social and so simultaneously contextualising the research and the researcher" (Schmid, 2019, p. 266). It is an approach to research and writing that seeks to describe and thoroughly analyse personal experiences to understand cultural experiences (ethno) (Ellis et al., 2011). It involves critical self-introspection and selfevaluation as a way of improving the quality of output (Duncan, 2004). The process records assumptions, perspectives and views, which may contribute to how a lecturer views or understands students. Further, the process develops ideas and creativity by capturing inner conversations (Duncan, 2004). It records the exact incidence points where someone experiences a change of thinking and understanding. The rigorous self-introspection involves experiencing, examining, observing and revealing (Wamsted, 2012).

Some limitations of the approach need to be acknowledged though. The process can be impeded by a failure to recall events, the inability to understand and interpret as well as the inability to convey messages (Wamsted, 2012). It focuses on experiences of the researcher (Denejkina, 2017), mostly using first-hand notation, which goes against most methodological approaches which separate the researcher from the subject. When not done retrospectively, it can require constant documentation of personal experiences to avoid loss of memory of emotion, ideas and details. While autoethnography is arguably a contested methodology because of such limitations, when conducted appropriately, it can produce transformative teaching in addition to the pedagogy of teaching. The downside is that accounts of personal experiences may be overemphasised or exaggerated, thereby giving a biased version of results and conclusions (Duncan, 2004). The approach taken tried to maximise on the strengths of the approach as well as minimise the shortcomings.

\section{Sample}

As autoethnography does not separate the researcher from the researched, a sample in autoethnography reflects the population. In this study, the population was three lecturers and the sample consisted of the three lecturers. The focus was on our online interactions at the one particular university where we lectured during the 2020 academic year. The sample suited the purpose of the study which is to uncover how we experienced and adjusted to online interactions with students during the 2020 academic year. As a qualitative approach was used, the sample is not generalisable to other populations. 
Makwembere, S. et al. Lecturer Autoethnographies of Adjusting to Online Student Interactions during COVID-19

\section{Data collection}

We discussed the objectives of our reflections and how to capture these over three weeks. One week was then dedicated to capturing our reflections. We each focused on an initial reflection of all the courses that we taught and then narrowed this to one course. We had to prepare journals to record our accounts (captured electronically), including evidence of encounters and actions, which were the basis for our findings and discussions. We had to stretch our minds and memories and include all we could remember of our thoughts, feelings, decisions and rationale for our decisions.

\section{Data analysis}

The recorded accounts were manually analysed using thematic analysis. One lecturer looked for patterns in the data then identified the main emerging themes. Two core themes were established and checked against literature. These core themes were discussed and agreed upon by the group.

\section{Ethical considerations}

With autoethnography, there are broader ethical considerations that are needed to be considered such as relational ethics where the experiences shared may have consequences for others, thus any sharing of information needs to take this into account. Our identities have been anonymised to respect confidentiality, anonymity and relational ethics principles. We are identified as Lecturer 1, Lecturer 2 and Lecturer 3.

What follows is the presentation of findings and discussion based on two main themes that emerged from the analysis of what was shared.

\section{Findings and discussion}

The following section presents the findings from our reflections and discussions on these. The three of us have between five to thirteen years' experience lecturing commerce and social science-related subjects in $\mathrm{HDI}$ contexts. The reflections capture the periods when we prepared for online interactions with students as well as when we started interacting with them online during the 2020 academic year. The main tools we used for interactions over the period included WhatsApp Messenger, Microsoft Teams, Google Meet and Blackboard (the selected institution's official learning management system). We chose when and how to use these tools guided by institutional policy frameworks. In explaining our experiences in adjusting to online interactions with students, two main themes emanated from the recorded accounts: alienation and accommodation and the use of coping strategies. These themes are the subject of the following discussions.

\section{Theme 1: Alienation and accommodation}

Alienation, which occurred in the teaching environment, was a shared experience. While university students experience alienation in online learning environments (Wei et al., 2012), the findings suggest that as lecturers, we also experienced the same alienation. This alienation emanated from decreased opportunities of engagement with students and peers, a lack of data resources to effectively perform our roles and insufficient preparation for the online transition. Factors such as isolation, insufficient resources and inadequate time to prepare were also 
Makwembere, S. et al. Lecturer Autoethnographies of Adjusting to Online Student Interactions during COVID-19

identified by Žižanović et al. (2021) as problematic for remote teaching. Linked to this, was a theme on accommodation whereby these were made in response to being insufficiently equipped to teach online. The alienation influenced most of our behaviours, responses and adjustments to remote teaching.

Individuals regulate their behaviours by constantly assessing the manner they do things in comparison with environmental circumstances (Bandura, 1986). We identified resource, leadership and information deficiencies over the period, more so, during the early institutional responses to COVID-19 with some improvements by the end of the period under observation. This resonates with the study by Czerniewicz et al. (2020) who argue that resources were inadequate to enable effective remote learning, especially at the start of remote teaching and learning. Whilst our institution attempted to address the resource limitation to enable teaching and learning to continue, the extent for this provision was constrained by budget affordances. Leadership vacuum could have been a result of the unpredictable nature of COVID-19 which made informed decision-making challenging (Czerniewicz et al., 2020).

The main resource we lacked was data to undertake research to prepare for courses, offer live classes and interact with students as well as peers regularly. Often, the data meant for teaching and learning was used to attend to administrative matters such as attending departmental meetings. These meetings were numerous during the period when lecturers were expected to start online classes. When recalling their experience during the time ERT had just been introduced, Lecturer 1 stated:

After receiving the router, the number of online meetings increased, ranging from departmental meetings, ... group meetings, and training colleagues. The $[\mathrm{X}]$ gigs of data I received was depleted in 6 days after attending 2 Blackboard collaborate and one MS Team meetings. The purchasing of expensive data, in addition to unstable network, compounded the negative experiences I had with online learning. In all meetings I was the presenter and using my own network provider (not provided by institution), I had to drive to another place and attend the meetings in a car or ask a friend for a place to attend the meetings from.

Lecturer 1 highlighted that the encounters of insufficient data led to personal accommodations of using personal finances. At times, Lecturer 1 had to seek various places to access better network coverage. When recalling the same period, Lecturer 2 uncovered similar challenges of insufficient data as Lecturer 1. They stated:

April to June were months of many meetings and trainings. The data I received just wasn't enough. I only conducted classes after that period because I did not want to incur higher personal costs trying to make sure I was present for meetings (some lasting 5 hours or even rolling over from one day to the next) and delivering classes. As much as I felt happy that online options were being pursued, I was not going to go out of pocket for the cause. I doubted I would ever be able to claim back any excess costs I incurred buying data so I tried to manage costs. In some of the long meetings, I wished I could just log off before they finished because they were on a platform that was not zero rated. Also, I found it annoying that the first thirty minutes was wasted with 'Can you hear me', 'Please switch off your camera', 'Please mute yourselves', 'I'm struggling 
Makwembere, S. et al. Lecturer Autoethnographies of Adjusting to Online Student Interactions during COVID-19

with connection', 'Let's wait for others to connect'. People were not yet used to online meetings. I just wondered how classes would be handled if meetings were handled this way.

Lecturer 2 expressed an unwillingness to incur additional personal costs because of this.

The online teaching environmental circumstances were characterised by the realities of inadequate resources for online interaction. Data allocation was inadequate and Internet access was mostly poor, something that was not unique to our case only but also identified by other authors who identified inadequate data and unstable network as constraints to remote teaching and learning (Kaisara \& Bwalya, 2020; Wilcox \& Vignal, 2020; Songca et al., 2021; Williams et al., 2021). As individuals, we incurred additional financial costs of sourcing data, a mechanism claimed by Zapata-Garibay et al. (2021) in their study. The lack of resources to participate in online activities had an alienating effect. The experiences revealed that the institution had not yet overcome its resource challenges and the impact of this was isolation despite the accommodations they made. The use of personal data seemed to be an accommodation linked to the urgent need to respond to COVID-19. The adaptions of incurring additional personal costs in terms of time and money reveal individual agency under the circumstances. However, not being able to freely and fully participate in online interactions due to the lack of resources had an alienating effect. In HDIs, alienation is an "embedded legacy of history" (Beresford, 2004).

Another accommodation that had to be made was that of allowing work to encroach more into home life. We had to adjust our home lives to fit in the new way of working. For example, Lecturer 3 stated that:

Balancing working from home and actual class delivery was a bit of a challenge mainly due to the situation just being unusual to the family and myself. I had to set up an office space in one of the rooms and had to always lock myself when having meetings or classes. It was difficult in the beginning especially having some meeting going on during lunch and after hours. There were actually no normal office hours followed. I had to decide and cut on the meetings that I attend and avoid some meetings where I felt I was not needed that much.

This statement suggests that for Lecturer 3, they had to make adjustments in their daily routines to ensure that the conditions were conducive for online class delivery. Work intruded on personal home space. As Shareena and Shahid (2020) found, at times, working from home was stressful, uncomfortable and disruptive. Each of us had partners and children at home. This meant that we had to fulfil our family responsibilities and deal with the expanded responsibilities that came with institutional adjustments to COVID-19. Our reflections pointed to tensions balancing family and work life during the early period of the year, a finding that was highlighted by Kim and Asbury (2020). Teachers had to put up with extra hours to cope with extra-ordinary workloads which was strenuous (Zapata-Garibay et al., 2021) and clashed with personal lives (Marshall et al., 2020).

In addition, these tensions took place while we had our anxieties about the pandemic. Lecturer 1 stated: 
Makwembere, S. et al. Lecturer Autoethnographies of Adjusting to Online Student Interactions during COVID-19

The major fear I had was the loss of lives rather than the teaching and learning of students. I had a sense of panic not sure if I and my family would survive the pandemic, if we will be able to stick to the precautionary measures, if I wouldn't get the virus from the shops I had to visit now and again. We started buying bread and other things in bulk to minimise the movement and limit catching the virus. How teaching would take place was not a key concern at the beginning.

Lecturer 1 had early anxieties about family surviving the pandemic than how teaching would take place. Family was an immediate priority. Personal and professional responsibilities had to be managed alongside managing anxieties about the risks of COVID-19. The sudden shift to remote learning was unsettling and led to socio-emotional stress, as argued by Schuck and Lambert (2020). The discomfort and anxiety we experienced was not an isolated case as other studies such as Kim and Asbury (2020), Johnson et al. (2020), Zapata-Garibay et al. (2021), Smith-Hawkins (2021) also identified anxiety as a consequence of adjusting to online interactions.

As much as we experienced challenges working from home, we were concerned about students' lack of resources and the challenges they possibly faced while studying from home. Most of our students who resided in remote rural areas, faced challenges ranging from insufficient data (Kaisara \& Bwalya, 2020), unstable network (Songca et al., 2021) and unconducive home environment (Obuaku-Igwe, 2020). These challenges constrained students from effectively engaging in remote learning. We empathised with the students in light of these challenges. Lecturer 3 stated:

The 2020 academic year was a challenging year for both lecturers and students. I felt for many students who did not have bursaries and reliable access to internet. I had to give students more time for assessment writing in some instances 12 hours while assessment is open. Some students were comfortable to write during the day while others preferred night time. So I had to accommodate all of them.

Making changes to assessment practices was an important accommodation for students. Zhang et al. (2021) argue that more fluid and dynamic circumstances of online teaching require adjustments in assessment practices.

Lecturer 2 recounted:

Before lockdown, my experience had been that about a quarter of the class would attend face to face classes, even with threats that non-attendance would have repercussions. Now we were in a situation where students were at their homes. What a disaster situation. I just imagined students' situations. Many likely wouldn't choose to not sit in and listen until an assessment on the materials was due but probably just weren't able to. Most lived in rural areas. Connectivity is poor in remote areas. I never checked the LMS statistics to know whether students were accessing materials. I thought it was unfair to use such statistics and I wanted to avoid being annoyed. Ignorance was bliss regarding this. 
Makwembere, S. et al. Lecturer Autoethnographies of Adjusting to Online Student Interactions during COVID-19

Lecturer 1 shared:

I was staying in an urban area and my network was pretty bad. I could now imagine the frustration a student deep in the remote rural area would feel about online learning. University campuses provided a shield to the social injustices where they had access to the institution's network, study spaces and discussion areas. Now that they were home, the inequalities were exposed. Thinking of all these possible challenges students could face made me feel like I was on an impossible mission.

These feelings were also noted by Kim and Asbury (2020) where teachers were concerned about the vulnerability of their pupils. Considering the pressure that the students were experiencing during remote learning (Benito et al., 2021), lecturers needed to support and encourage their students to enable effective student learning (Aristovnik et al., 2020). Studies by Songca et al. (2021), Yuan (2021) and Benito et al. (2021) found and reported that lecturers showed compassion, commitment, empathy and understanding towards their interactions with students during remote learning.

While we could empathise with students, we sensed that we were encountering a situation, which we had little control over. As people "act on their judgments of what they can do as well as on their beliefs about the likely effects of various actions" (Bandura, 1986, p. 231), we executed specific courses of action amidst complex personal, behavioural and contextual factors. We recognised the alienated positions many students faced due to their socioeconomic backgrounds. We made accommodations where this was possible, for example, by overlooking statistics tracking student activity.

\section{Theme 2: Use of coping strategies}

The need to cope with the stress associated with the shift to ERTL was another major theme. Coping strategies were employed amidst fears of the new situation, which involved changes in teaching and learning methodologies to interact with students online. The fears exhibited in the reviews were also reported by Kim and Asbury (2020) who claimed that teachers felt overwhelmed by the changes they were experiencing. The strategies included problemfocused strategies, avoidant strategies as well as emotional support (Maclntyre et al., 2020). The context in which these coping strategies were applied was characterised by factors (technical and non-technical) such as revisions to the academic year, which affected teaching schedules, pressures to complete all teaching within a limited time; poor network coverage of service providers; delays or absence of comprehensive managerial instructions; persistent data and network access challenges as well as knowledge gaps on how to use certain online platforms. These factors were also highlighted in several other studies (Czerniewicz et al., 2020; Ferri et al., 2020; Kaisara \& Bwalya, 2020; Songca et al., 2021). These strategies seemed to instil a sense of coping self-efficacy to varying degrees. The stronger the instilled sense of coping self-efficacy, the bolder the behaviour (Bandura, 1982).

We had to alternate between live online classes and other ways such as sharing pre-recorded videos on WhatsApp, choosing when to engage with students during the teaching and learning. These coping strategies contributed to our self-efficacy. 
Makwembere, S. et al. Lecturer Autoethnographies of Adjusting to Online Student Interactions during COVID-19

When recalling the way they coped with the new teaching situations, Lecturer 1 stated:

My first virtual session on MS Teams was in early August and since then, started meeting the...students on a weekly basis. This session was very unpleasant and unstable, the network played a huge role in this unpleasantness. Students complained that I was inaudible and they could barely follow the class discussions, very few participated. I also noticed that several students were being kicked out of the session which impacted the engagements. To add to the discomfort, I didn't know which functions were best suited for my students and the students didn't make the situation any better by not participating. Some of the students had their microphones unmuted, which greatly distracted the session. For some, even after muting them, they would unmute themselves for the reasons I am unaware of...The poor network connection meant that I had to have my classes at places where the network was stable. I had to drive somewhere, away from my place of accommodation, most of the time. I had to conduct the classes mostly in the car or a friend's places. This wasn't a good experience as it didn't offer privacy and I could easily be distracted. It also increased the risk of being robbed of the equipment.

Lecturer 1 expressed a sense of displeasure. Further, Lecturer 1 said:

Whilst WA [WhatsApp] enabled a better experience, it was difficult to control and was at times flooded with consultations at the same time, especially closer to the times for assessments. Some students also sent enquiries late into the night. I did not mind messages being sent at those times but would normally not respond until morning. ...

All these approaches I had to adopt without proper guidance from leadership. Many people shared my feelings, my experiences could have been better with timely communication and direction. The feelings of despair were made worse by different stories being said along the corridors, including moving to another learning management system. This did not, however affect me much as I did not mind learning new ways and had already adopted WA [WhatsApp] and MS [Microsoft Teams] as my preferred platforms where I would integrate with google forms and YouTube. Lack of timely communication from authorities gave me the autonomy to try a number of other ways to interact with students.

Lecturer 1 was able to use problem-focused coping skills. The absence of clear instructions and direction lead to numerous challenges as was also found by Žižanović et al. (2021). It should, however be noted that the lack of guidance could have been caused by the difficulty in making substantive decisions because of the nature of the pandemic, which was unpredictable (Czerniewicz et al., 2020). It was therefore, difficult for leaders to make decisions without proper understanding of the behaviour of the virus.

Also reflecting on the way they coped with the demands of the new online teaching situations Lecturer 2 stated:

Shifts in the academic calendar caused confusion for my plans. September to November was a time I just tried to squeeze as much as possible. Assessments were done, in most cases without comprehensive feedback, just general feedback. I was starting to feel 
Makwembere, S. et al. Lecturer Autoethnographies of Adjusting to Online Student Interactions during COVID-19

overwhelmed with demands. While instruction was received that teaching could end by December, my understanding was that I needed to complete everything before end of November...I was constantly tired and at times ignored my work phone for a few days to pretend that I didn't have students asking for clarity on assignments, whether or not they would have to write exams.

Lecturer 2 recalled how they felt overwhelmed with demands and used avoidant coping strategies.

Obtaining emotional support is an important coping strategy (Maclntyre et al., 2020). At times, we proactively created collegial support systems which we contributed to and benefited from. Our self-efficacy contributed to our agency as well as the collective agency of lecturers as a group.

Personal factors facilitated opportunities to support colleagues and students. Lecturer 3 said:

Generally, I do not panic and get anxiety especially when caused by the situation beyond my control. So I was always engaging students even when they were pointing that time is going to remain calm. I was also mentoring and engaging other staff members who were beginning to panic as the year progresses. So I somehow played a role in calming both my peers and students and in each of my lectures I always encouraged my students to adhere to COVID-19 regulations.

Lecturer 3 pointed to a personality trait that contributed to not being anxious. This enabled better coping of the pressured situations and provision of support to students and colleagues. Using coping mechanisms when going through the challenging period proved to be valuable for all of us as such mechanisms build resilience (Subedi \& Subedi, 2020).

\section{Recommendations}

The interaction between personal, behavioural and contextual or environmental factors while adjusting to online interactions with students is revealed in the excerpts of the autoethnographies. What follows are recommendations on ways to enhance lecturer abilities to adjust to online learning in HDI contexts.

\section{Encourage compassionate agency}

Lecturers are agents of change. Lecturer's thoughts and feelings affect their behaviour and their behaviour can change HDI environments positively or negatively. Having concern for not just knowledge on the implications of behaviours could direct decision-making towards more positive outcomes. For example, lecturers can be encouraged to interrogate their actions of unreasonably limiting interactions with students as a reinforcement of student realities of marginalisation and historic social injustices.

\section{Allow flexibility with guided support}

Allowing flexibility in coping strategies as lecturers cope with making adjustments needed for online learning can improve their self-efficacy. The benefit would be that lecturers who know their abilities and lecturing contexts well can be positioned to respond appropriately to shifting circumstances. This flexibility with guided support could have positive outcomes as rigidity could result in lost opportunities to cater to unique student needs. 
Makwembere, S. et al. Lecturer Autoethnographies of Adjusting to Online Student Interactions during COVID-19

\section{Relevance of autoethnography in South African Historically Disadvantaged Institutions}

Autoethnography can facilitate viewpoints and expose misrepresentations of happenings at HDIs. These viewpoints can challenge hegemonic discourse that reinforces the labels of HDI as, for example, unchanging or unresponsive to higher education priorities to develop or an absence of resources to an absence of agency to enable positive education outcomes. There needs to be a "validation" (Whitinui, 2014) of the importance of the 'self' in the bigger picture of transformation at HDIs. Elevating the voices of individuals at HDI can allow them to share their realities as they see and experience them.

While autoethnography would be useful for research on HDIs, it would require capacitating people on how to use it. This is pivotal because sharing experiences may cause anxieties about the consequences of sharing reflectively, for example, losing jobs or compromised professional integrity. Reflection needs to be understood as an integral part of transformation through individual agency. As the methodology is presently not widely used for research on South African HDIs, efforts to enhance its validity within the academic community should be made so that it is accommodated and those that use it for studies are not overlooked by scholarly conventions that already suffer from challenges such as gatekeeping.

The intention of autoethnography is never to recall facts and events but to "lift out" and "share" "meaning from (marginalised) experiences" (Schmid, 2019, p. 273). The recalling can compromise individuals or even the institutions. Therefore, ethics must be thoughtfully handled to minimise any harm to those directly or indirectly affected by the use of the approach.

\section{Conclusion}

Our adjustments to online instruction during remote learning was not smooth sailing due to a myriad of challenges faced by the selected institution and students we interacted with, where the majority were residing in remote rural areas. Through the reflective journals, the major constraints to adjustments to remote teaching included insufficient data, poor internet connection, technical challenges and perceived lack of support. Despite the alienations we experienced, mainly due to the aforementioned factors, we banked on our agentic powers to get around these challenges and interact with our students. This, we managed primarily through our self-efficacy which positively influenced teaching and learning. The social support that we provided to students and colleagues also made our online interactions much easier.

COVID-19 has resulted in a myriad of changes at HDIs. The accounts captured in the article point to some of what was encountered for one academic year. We did not capture all experiences and meanings relating to online interactions with students but we shed light on experiences and processes that took place that may have gone unexplored. The contexts of historically disadvantaged HEls warrant innovative methodologies that place the researchers as agents that are not far removed from their contexts but recognise their agencies in the structures and cultures produced and reproduced through the research process. Thus, autoethnographic approaches can achieve this innovatively, contributing to understanding the factors responsible for transformations at HDIs under COVID-19 and other situations.

\section{Disclosure and conflict of interest}

The authors declare that they have no conflict of interest. 
Makwembere, S. et al. Lecturer Autoethnographies of Adjusting to Online Student Interactions during COVID-19

\section{References}

Andreu, H. B., \& Nussbaum, M. (2009). An experimental study of the inclusion of technology in higher education. Computer Applications in Engineering Education, 17(1), 100-107. https://doi.org/10.1002/cae.20188

Arias, J. J., Swinton, J., \& Anderson, K. (2018). Online Vs. Face-to-Face: A Comparison of Student Outcomes with Random Assignment. Journal of Business Education \& Scholarship of Teaching, 12(2), 1-23.

Aristovnik, A., Keržič, D., Ravšelj, D., Tomaževič, N., \& Umek, L. (2020). Impacts of the COVID19 pandemic on life of higher education students: A global perspective. Sustainability (Switzerland), 12(20), 1-34. https://doi.org/10.3390/su12208438

Badat, S. (2010). The Challenges of Transformation in Higher Education and Training Institutions in South Africa. Development Bank of South Africa, April, 1-37. http://www.ru.ac.za/media/rhodesuniversity/content/vc/documents/The Challenges of Transformation in Higher Eduaction and Training Institutions in South Africa.pdf

Baldwin, H., \& Bekithemba, D. (2021). Covid-19 and the entrenchment of a virtual Elite private school: Rethinking education policies in Zimbabwe. Journal of Culture and Values in Education. https://doi.org/10.46303/jcve.2021.5

Bandara, D., \& Wijekularathna, D. . (2017). Comparison of student performance under two teaching two teaching methods: face to face and online. The International Journal of Educational Research, 12(1), 69-79.

https://www.thefreelibrary.com/COMPARISON+OF+STUDENT+PERFORMANCE+UNDER+ TWO+TEACHING+METHODS\%3A+FACE+TO...-a0517626096

Bandura, A. (1971). Social learning theory. In General Learning Press. https://doi.org/10.1016/B978-0-12-813251-7.00057-2

Bandura, A. (1977). Self-efficacy: Toward a unifying theory of behavioral change. Psychological Review, 84(2), 191-215. https://doi.org/https://doi.org/10.1037/0033295X.84.2.191

Bandura, A. (1982). Bandura, A. (1982). Self-efficacy mechanism in human agency. American Psychologist, 37(2), 122-147. https://doi.org/10.1037/0003-066X.37.2.122

Bandura, A. (1986). Social foundations of thought and action: A social cognitive theory. Prentice- Hall, Inc.

Bandura, A. (1999). A social cognitive theory of personality. In L. Pervin \& O. John (Eds.), Handbook of personality (2nd ed.). Guilford Publications.

https://www.google.com/books?hl=en\&lr=\&id=b0yalwi1HDMC\&oi=fnd\&pg=PA154\&dq= Social+cognitive+theory+of+personality\&ots=767yO2WqNj\&sig=yJSrel-

r7pTwEDiqNK1VhqoMDfw

Bandura, A. (2001). Social Cognitive Theory: An Agentic Perspective. Annual Review of Psychology, 52(1), 1-26.

Bandura, A. (2005). The Evolution of Social Cognitive Theory. In K. G. Smith \& M. A. Hitt (Eds.), Great Minds in Management (pp. 9-35). Oxford University Press.

Benito, Á., Yenisey, K. D., Khanna, K., Masis, M. F., Monge, R. M., Tugtan, M. A., Araya, L. D. V., \& Vig, R. (2021). Changes That Should Remain in Higher Education Post COVID-19: A Mixed-Methods Analysis of the Experiences at Three Universities. Higher Learning Research Communications, 11(0), 51-75. https://doi.org/10.18870/hlrc.v11i0.1195 
Makwembere, S. et al. Lecturer Autoethnographies of Adjusting to Online Student Interactions during COVID-19

Beresford, Q. (2004). Indigenous Alienation from School and "the Embedded Legacy of History": The Australian Experience. International Journal on School Disaffection, 2, 6-13. https://doi.org/https://doi.org/10.18546/IJSD.02.2.03

Chetty, R., \& Pather, S. (2015). Challenges in Higher Education in South Africa. Telling Stories Differently: Engaging 21st Century Students Through Digital Storytelling, 1-6.

Czerniewicz, L., Agherdien, N., Badenhorst, J., Belluigi, D., Chambers, T., Chili, M., de Villiers, M., Felix, A., Gachago, D., Gokhale, C., Ivala, E., Kramm, N., Madiba, M., Mistri, G., Mgqwashu, E., Pallitt, N., Prinsloo, P., Solomon, K., Strydom, S., Swanepoel, M., Waghid, F., \& Wissing, G. (2020). A Wake-Up Call: Equity, Inequality and Covid-19 Emergency Remote Teaching and Learning. Postdigital Science and Education, 2(3), 946-967. https://doi.org/10.1007/s42438-020-00187-4

Denejkina, A. (2017). Exo-autoethnography: An introduction. Forum Qualitative Sozialforschung, 18(3). https://doi.org/10.17169/fqs-18.3.2754

Deparment of Higher Education and Training. (2014). Report of the Ministerial Committee for the Review of the Funding of Universities. Department of Higher Education and Training.

Duncan, M. (2004). Autoethnography: Critical Appreciation of an Emerging Art. International Journal of Qualitative Methods, 3(4), 28-39. https://doi.org/10.1177/160940690400300403

Ellis, C., Adams, T. E., \& Bochner, A. P. (2011). Autoethnography: An overview. Historical Social Research, 36(4), 273-290. https://doi.org/10.17169/fqs-12.1.1589

Ferri, F., Grifoni, P., \& Guzzo, T. (2020). Online Learning and Emergency Remote Teaching: Opportunities and Challenges in Emergency Situations. Societies, 10(86). https://doi.org/10.3390/soc10040086

Fertman, C., \& Primack, B. (2009). Elementary student self efficacy scale development and validation focused on student learning, peer relations, and resisting drug use. Journal of Drug Education, 39(1), 23-38. https://doi.org/10.2190/DE.39.1.b

Fulton, K. (2012). Upside down and inside out : Flip your classroom to improve student learning. Learning \& Leading with Technology, 39(8), 12-17.

Gherheș, V., Stoian, C. E., Fărcașiu, M. A., \& Stanici, M. (2021). E-learning vs. Face-to-face learning: Analyzing students' preferences and behaviors. Sustainability (Switzerland), 13(8). https://doi.org/10.3390/su13084381

Johnson, N., Veletsianos, G., \& Seaman, J. (2020). U.S. faculty and administrators' experiences and approaches in the early weeks of the COVID-19 pandemic. Online Learning Journal, 24(2), 6-21. https://doi.org/10.24059/olj.v24i2.2285

Joia, L. A., \& Lorenzo, M. (2021). Zoom in, zoom out: The impact of the covid-19 pandemic in the classroom. Sustainability (Switzerland), 13(5), 1-18. https://doi.org/10.3390/su13052531

Julien, G., \& Dookwah, R. (2020). Students transition from face to face learning to online learning at higher education: A case study in Trinidad and Tobago. Educational Research and Reviews, 15(8), 487-494. https://doi.org/10.5897/err2020.4005

Kaisara, G., \& Bwalya, K. J. (2020). Investigating the E-Learning Challenges Faced by Students during Covid-19 in Namibia. International Journal of Higher Education, 10(1), 308-318. https://doi.org/10.5430/ijhe.v10n1p308

Kalimullina, O., Tarman, B. \& Stepanova, I. (2021). Education in the Context of Digitalization 
Makwembere, S. et al. Lecturer Autoethnographies of Adjusting to Online Student Interactions during COVID-19

and Culture: Evolution of the Teacher's Role, Pre-pandemic Overview. Journal of Ethnic and Cultural Studies, 8(1), 226-238. DOI: http://dx.doi.org/10.29333/ejecs/629

Khogali, H. A. (2020). The Effect of COVID-19 CORONA VIRUS on Sustainable Teaching and Learning in Architecture Engineering. Modern Applied Science, 14(8), 44-58. https://doi.org/10.5539/mas.v14n8p44

Kim, L. E., \& Asbury, K. (2020). 'Like a rug had been pulled from under you': The impact of COVID-19 on teachers in England during the first six weeks of the UK lockdown. British Journal of Educational Psychology, 90(4), 1062-1083. https://doi.org/10.1111/bjep.12381

Li, Y., Zhang, M., Bonk, C. J., \& Guo, Y. (2015). Integrating mooc and flipped classroom practice in a traditional undergraduate course: Students' experience and perceptions. International Journal of Emerging Technologies in Learning, 10(6), 4-10. https://doi.org/10.3991/ijet.v10i6.4708

Maclntyre, P. D., Gregersen, T., \& Mercer, S. (2020). Language teachers' coping strategies during the Covid-19 conversion to online teaching: Correlations with stress, wellbeing and negative emotions. System, 94. https://doi.org/10.1016/j.system.2020.102352

Marshall, D. T., Shannon, D. M., \& Love, S. M. (2020). How teachers experienced the COVID19 transition to remote instruction. Phi Delta Kappan, 102(3), 46-50. https://doi.org/10.1177/0031721720970702

Matarirano, O., Jere, N. R., Sibanda, H. S., \& Panicker, M. (2021). Antecedents of Blackboard Adoption by Lecturers at a South African Higher Education Institution - Extending GETAMEL. International Journal of Emerging Technologies in Learning, 16(1), 60-79. https://doi.org/10.3991/IJET.V16I01.16821

Matarirano, O., Panicker, M., Jere, N. R., \& Maliwa, A. (2021). External factors affecting blackboard learning management system adoption by students: Evidence from a historically disadvantaged higher education institution in South Africa. South African Journal of Higher Education, 35(2), 188-206. https://doi.org/http://dx.doi.org/10.20853/35-2-4025

Mekoa, I. (2018). African Renaissance - Challenges facing higher education in South Africa: a change from apartheid education to democratic education. African Renaissance, 15(2), 227-246.

Meishar-Tal, H., \& Levenberg, A. (2021). In times of trouble: Higher education lecturers' emotional reaction to online instruction during COVID-19 outbreak. Education and Information Technologies, 1-17. https://doi.org/10.1007/s10639-021-10569-1

Naveed, N. Q., Muhammad, A., Sanober, S., Qureshi, R. M. N., \& Shah, A. (2017). A Mixed Method Study for Investigating Critical Success Factors (CSFs) of E-Learning in Saudi Arabian Universities. International Journal of Advanced Computer Science and Applications, 8(5), 171-178. https://doi.org/10.14569/ijacsa.2017.080522

Nyoni, P. N. (2020). Pedagogy and Agency in Postgraduate Student Supervision in a Rural South African University. In D. . Atibuni (Ed.), Postgraduate Research Engagement in Low Resource Settings (pp. 296-316). (pp. 296-316). IGI Global. https://doi.org/http://doi:10.4018/978-1-7998-0264-8.ch015

Obuaku-Igwe, C. (2020). 'Umuntu ngumuntu ngabantu' (a person is a person because of other people): reflections on student's experiences of social isolation and the impact of a peer 
Makwembere, S. et al. Lecturer Autoethnographies of Adjusting to Online Student Interactions during COVID-19

to peer mental health support group during covid-19 lockdown in South Africa. Youth Voice Journal, 2020, 58-71.

Pozzi, F., Manganello, F., Passarelli, M., Persico, D., Brasher, A., Holmes, W., Whitelock, D., \& Sangrà, A. (2019). Ranking meets distance education: Defining relevant criteria and indicators for online universities. International Review of Research in Open and Distance Learning, 20(5), 42-63. https://doi.org/10.19173/irrodl.v20i5.4391

Radha, R., Mahalakshmi, K., Kumar, V. S., \& Saravanakumar, A. R. (2020). E-Learning during Lockdown of Covid-19 Pandemic: A Global Perspective. International Journal of Control and Automation, 13(4), 1088-1099.

Rashid, S., \& Yadav, S. S. (2020). Impact of Covid19 pandemic on higher education and research. Indian Journal of Human Development, 14(2), 340-343.

https://doi.org/https://doi.org/10.1177\%2F0973703020946700

Sahu, P. (2020). Closure of Universities Due to Coronavirus Disease 2019 (COVID-19): Impact on Education and Mental Health of Students and Academic Staff. Cureus, 2019(April). https://doi.org/10.7759/cureus.7541

Schmid, J. (2019). Autoethnography: Locating the self as standpoint in post-apartheid South Africa. In S. Laher, A. Fynn, \& S. Kramer (Eds.), Transforming Research Methods in the Social Sciences: : Case Studies from South Africa (pp. 265-279). Wits University Press. https://doi.org/10.18772/22019032750.22

Schuck, R. K., \& Lambert, R. (2020). “Am I Doing Enough?” Special Educators' Experiences with Emergency Remote Teaching in Spring 2020. Education Sciences, 10(11), 1-15. https://doi.org/10.3390/educsci10110320

Schunk, D. H., \& Usher, E. L. (2012). The Oxford Handbook of Human Motivation. In R. M. Ryan (Ed.), Oxford University Press.

Shareena, P., \& Shahid, M. (2020). Work from home during COVID-19 : Employees perception and experiences. Gjra - Global Journal for Research Analysis, 9(5), 7-10.

Smith-Hawkins, P. (2021). A Qualitative Study of Faculty Responses to Teaching during the Covid-19 Pandemic: Creating a Culture of Support. Journal of Education, Teaching and Social Studies, 3(1), 67-77. https://doi.org/10.22158/jetss.v3n1p67

Songca, R. N., Ndebele, C., \& Mbodila, M. (2021). Mitigating the Implications of Covid-19 on the Academic Project at Walter Sisulu University in South Africa: A Proposed Framework for Emergency Remote Teaching and Learning. Journal for Students Affairs in Africa, 9(1), 41-60. https://doi.org/10.24085/jsaa.v9i1.1427

Sonn, R. (2016). The challenge for a historically disadvantaged South African university to produce more postgraduate students. South African Journal of Higher Education, 30(2), 226-241. https://doi.org/10.20853/30-2-601

Subedi, D., \& Subedi, R. (2020). Practicing Self Learning of ICT for Resilience Amidst the COVID-19 Outbreak: Experiences from Kathmandu Valley. Research in Educational Policy and Management, 2(2), 78-96. https://doi.org/10.46303/repam.2020.5

UNESCO. (2021). Education: From disruption to recovery. https://en.unesco.org/covid19/educationresponse

Wamsted, J. O. (2012). Borges \& Bike Rides: Toward an Understanding of Autoethnography. Qualitative Research in Education, 1(2), 179-201. https://doi.org/10.4471/qre.2012.09

Wei, C. W., Chen, N. S., \& Kinshuk. (2012). A model for social presence in online classrooms. 
Makwembere, S. et al. Lecturer Autoethnographies of Adjusting to Online Student Interactions during COVID-19

Educational Technology Research and Development, 60(3), 529-545.

https://doi.org/10.1007/s11423-012-9234-9

Whitinui, P. (2014). Indigenous Autoethnography: Exploring, Engaging, and Experiencing

"Self" as a Native Method of Inquiry. Journal of Contemporary Ethnography, 43(4), 456487. https://doi.org/10.1177/0891241613508148

Wilcox, B. R., \& Vignal, M. (2020). Understanding the student experience with emergency remote teaching. In Wolf, Bennett and Frank (Eds.), The Physics Education Research Conference (pp. 581-586). American Association of Physics Teachers.

https://doi.org/10.1119/perc.2020.pr.wilcox

Williams, T. K., McIntosh, R. W., \& Russell, W. B. (2021). Equity in Distance Education During COVID-19. Research in Social Sciences and Technology, 6(1), 1-24.

https://doi.org/10.46303/ressat.2021.1

Yorguner, N., Bulut, N. S., \& Akvardar, Y. (2021). An Analysis of the Psychosocial Challenges Faced by the University Students During COVID-19 Pandemic, and the Students' Knowledge, Attitudes, and Practices Toward the Disease. Archives of Neuropsychiatry, 58(1), 3-10. https://dx.doi.org/10.29399\%2Fnpa.27503

Yuan, L. M. (2021). Student's Attitude and Satisfaction towards Transformative Learning: A Research Study on Emergency Remote Learning in Tertiary Education. Creative Education, 12(03), 494-528. https://doi.org/10.4236/ce.2021.123035

Zapata-Garibay, R., González-Fagoaga, J. E., González-Fagoaga, C. J., Cauich-García, J. R., \& Plascencia-López, I. (2021). Higher Education Teaching Practices Experience in Mexico, During the Emergency Remote Teaching Implementation due to COVID-19. Frontiers in Education, 6. https://doi.org/10.3389/feduc.2021.628158

Zhang, C., Yan, X., \& Wang, J. (2021). EFL Teachers' Online Assessment Practices During the COVID-19 Pandemic: Changes and Mediating Factors. Asia-Pacific Education Researcher. https://doi.org/10.1007/s40299-021-00589-3

Žižanović, S., Pranjić, S. S., \& Radovanović, M. (2021). Educational Challenges of Emergency Remote Teaching and Learning During the Coronavirus Crisis. Proceedings of INTCESS 2021 8th International Conference on Education and Education of Social Sciences, 231241. https://doi.org/10.51508/intcess.2021168 